Abstract Table 2. Multivariate analysis. Variables associated to IEXPAC experience scores. Beta coeff. (SD): Beta coefficient (standard deviation). Positive coefficients indicate higher IEXPAC experience scores (better experience). SC: subcutaneous; IV: intravenous.

\begin{tabular}{|c|c|c|c|c|c|c|c|c|}
\hline \multirow[t]{2}{*}{ Parameter } & \multicolumn{2}{|c|}{$\begin{array}{c}\text { Overall } \\
\text { experience } \\
\text { score }\end{array}$} & \multicolumn{2}{|c|}{$\begin{array}{l}\text { Productive } \\
\text { Inter actions } \\
\text { (Factor 1) }\end{array}$} & \multicolumn{2}{|c|}{\begin{tabular}{c|} 
New \\
Relational \\
Model \\
(Factor 2) \\
\end{tabular}} & \multicolumn{2}{|c|}{$\begin{array}{c}\text { Patient Self- } \\
\text { management } \\
\text { (Factor 3) }\end{array}$} \\
\hline & $\begin{array}{l}\text { Beta } \\
\text { coeff. }\end{array}$ & $P$ & $\begin{array}{l}\text { Beta } \\
\text { coeff. }\end{array}$ & $P$ & \begin{tabular}{l|} 
Beta \\
coeff.
\end{tabular} & $P$ & \begin{tabular}{l|l} 
Beta \\
coeff.
\end{tabular} & $P$ \\
\hline Sex (women vs. men) & $\begin{array}{l}-0.43 \\
(0.28)\end{array}$ & 0.132 & $\begin{array}{l}-0.65 \\
(0.36)\end{array}$ & 0.073 & \begin{tabular}{c|}
-0.13 \\
$(0.30)$
\end{tabular} & 0.663 & $\begin{array}{l}-0.46 \\
(0.35)\end{array}$ & 0.189 \\
\hline $\begin{array}{l}\text { Age (per year of } \\
\text { increment) }\end{array}$ & $\begin{array}{l}0.00 \\
(0.01)\end{array}$ & 0.715 & $\begin{array}{l}0.01 \\
(0.01)\end{array}$ & 0.682 & \begin{tabular}{|l|}
-0.00 \\
$(0.01)$
\end{tabular} & 0.886 & $\begin{array}{c}0.01 \\
(0.01)\end{array}$ & 0.659 \\
\hline $\begin{array}{l}\text { Educational level } \\
\text { achieved (university or } \\
\text { further) }\end{array}$ & $\begin{array}{r}-0.02 \\
(0.19)\end{array}$ & 0.933 & $\begin{array}{l}-0.28 \\
(0.24)\end{array}$ & 0.251 & $\begin{array}{c}0.32 \\
(0.20)\end{array}$ & 0.112 & $\begin{array}{l}-0.03 \\
(0.23)\end{array}$ & 0.886 \\
\hline $\begin{array}{l}\text { Follow-up in a region } \\
\text { different from home } \\
\text { region (vs. same region) }\end{array}$ & $\begin{array}{l}0.62 \\
(0.54)\end{array}$ & 0.252 & $\begin{array}{l}0.09 \\
(0.68)\end{array}$ & 0.896 & $\begin{array}{c}1.11 \\
(0.57)\end{array}$ & \begin{tabular}{|c|c}
0.053 \\
\end{tabular} & $\begin{array}{c}0.78 \\
(0.67)\end{array}$ & 0.243 \\
\hline Barthel Index $>80$ & $\begin{array}{r}0.28 \\
(0.37)\end{array}$ & 0.45 & $\begin{array}{r}0.26 \\
(0.47)\end{array}$ & 0.578 & \begin{tabular}{|l|}
0.48 \\
$(0.39)$
\end{tabular} & 0.226 & $\begin{array}{c}0.27 \\
(0.46)\end{array}$ & 0.554 \\
\hline $\begin{array}{l}\text { Number of specialists } \\
\text { visited in the last year } \\
\text { (per unit of increment) }\end{array}$ & $\begin{array}{l}-0.11 \\
(0.06)\end{array}$ & 0.080 & $\begin{array}{l}-0.14 \\
(0.08)\end{array}$ & 0.082 & $\begin{array}{l}-0.05 \\
(0.07)\end{array}$ & 0.447 & $\begin{array}{l}-0.12 \\
(0.08)\end{array}$ & 0.122 \\
\hline $\begin{array}{l}\text { Follow-up by the same } \\
\text { physician (vs. different) }\end{array}$ & \begin{tabular}{c|}
0.84 \\
$(0.26)$
\end{tabular} & 0.001 & $\begin{aligned} 1.17 \\
(0.33)\end{aligned}$ & $<0.001$ & \begin{tabular}{c|}
0.08 \\
$(0.27)$
\end{tabular} & \begin{tabular}{|l|l} 
& 0.773 \\
\end{tabular} & \begin{tabular}{c|}
1.15 \\
$(0.32)$
\end{tabular} & $<0.001$ \\
\hline $\begin{array}{l}\text { Follow-up by a nurse } \\
\text { (vs. no nurse follow- up) }\end{array}$ & $\begin{array}{c}0.10 \\
(0.29)\end{array}$ & 0.738 & $\begin{array}{l}-0.08 \\
(0.37)\end{array}$ & 0.822 & \begin{tabular}{|c|}
0.43 \\
$(0.31)$
\end{tabular} & 0.167 & $\begin{array}{l}-0.04 \\
(0.36)\end{array}$ & 0.914 \\
\hline $\begin{array}{l}\text { Having help from others } \\
\text { for care (vs. only self- } \\
\text { care) }\end{array}$ & $\begin{array}{c}0.30 \\
(0.30)\end{array}$ & 0.308 & $\begin{array}{c}0.09 \\
(0.38)\end{array}$ & 0.809 & $\begin{array}{c}0.42 \\
(0.32)\end{array}$ & $\mid 0.189$ & $\begin{array}{c}0.49 \\
(0.36)\end{array}$ & 0.178 \\
\hline $\begin{array}{l}\text { Number of different } \\
\text { medicines (per unit of } \\
\text { increment) }\end{array}$ & $\begin{array}{r}-0.03 \\
(0.06)\end{array}$ & 0.580 & $\begin{array}{l}-0.05 \\
(0.07)\end{array}$ & 0.454 & $\begin{array}{c}0.01 \\
(0.06)\end{array}$ & 0.927 & $\begin{array}{c}0.00 \\
(0.07)\end{array}$ & 0.958 \\
\hline $\begin{array}{l}\text { Being treated with } \\
\text { SCIV drugs (vs.no } \\
\text { SCIV treatment) }\end{array}$ & $\begin{array}{c}0.64 \\
(0.27)\end{array}$ & 0.021 & $\begin{array}{c}0.87 \\
(0.35)\end{array}$ & 0.013 & $\begin{array}{c}0.32 \\
(0.29)\end{array}$ & 0.275 & $\begin{array}{c}0.69 \\
(0.33)\end{array}$ & 0.040 \\
\hline
\end{tabular}

Acknowledgement: Funded by MSD of Spain and endorsed by 4 patients associations: ACCU, CONARTRITIS, SEISIDA, FEDE. We thank the participant patients for providing this valuable information by completing the survey.

Disclosure of Interests: Javier de Toro-Santos: None declared, María L. García Vivar: None declared, Lucía Pantoja: None declared, Cristina Lerín Lozano: None declared, Silvia García-Díaz: None declared, Yvonne Mestre Employee of: MSD, Sabela Fernández Employee of: MSD, Luis Cea-Calvo Employee of: MSD

DOI: 10.1136/annrheumdis-2019-eular.2759

\section{AB1208 POINT PREVALENCE OF UVEITIS AND ARTHRITIS AMONG SCHOOL CHILDREN IN A DEVELOPING COUNTRY}

Eiman Dessouki. Faculty of medicine, Alexandria university, Alexandria, Egypt

Background: Sight-threatening uveitis associated with pediatric rheumatologic diseases, especially juvenile idiopathi arthritis, often remains asymptomatic till late. On the other hand, children with indolent asymptomatic uveitis may later on develop the characteristic arthritis of juvenle idiopathic arthritis, especially the oligoarticular rheumatoid factor negative type. A multidiscipliary screening of children at the peak age of developing these potentially handicappinng manifestations, allows active case findng and facilitates a comprehensive ophthalmic-rheumatolgic management plan.

Objectives: A point prevalence study aiming at active case finding and describng the prevalence of uveitis and arthritis among school children between the ages of 4 and 9 years in 10 screened schools in Egypt.

Methods: All children between the ages of 4 and 9 years in 10 schools were screened for the clinical evidence of uveitis and/or arthritis. The children discovered to be suffering from uveitis and/or arthritis, were referred to the appropriate tertiary clinics for detailed evaluation and management

Results: A total of 6372 children were screened, 3418 of them were females $(53.6 \%)$ and 2954 were males $(46.4 \%)$. Thirty four children were found to have uveitis $(0.5 \%)$. Of these, 26 children were females $(76.5 \%)$ and 8 children were males (23.5\%). Two female children were known uveitis patients and were on treatment. A hundred and eleven children had arthralgia. Of these, 56 children had clinically evident arthritis at the time of screening. Twenty eight children with arthritis were females $(50 \%)$ and the other twenty eight children were males $(50 \%)$. Three girls were previously known to be arthritis patients ( 2 with juvenile idiopathc arthritis and one with psoriasis). Sixteen children had both uveitis and arthritis. All cases detected to have uveitis, arthralgia, or arthritis, in the study were referred to tertiary clinics for further management.

Conclusion: Screening of school children for uveitis and joint manifestations in developing countries with a modest socioeconomic status, is a method of active case finding that helps an, as early as possible, implementation of the proper plan of mangement.

\section{REFERENCES}

[1] Kanski JJ, Shun-Shin A. Systematic uveitis syndromes in childhood; an analysis of 340 cases. Ophthalmology 1984; 91: 1247-1252.

[2] Chang JH-M, Wakefield D. Uveitis: a global perspective. Ocul Immunol Inflamm. 2002; 10: 263-279:

[3] O'Brien JM, Albert DM. Therapeutic approaches for ophthalmic problems in juvenile arthritis. Rheumatol Dis Clin N Amer 1989; 15: 413-22.

[4] Tsirouki T, Dastiridou A, Symeonidis C, et al. A focus on the epidemiology of Uveitis. Ocul Immunol Inflamm 2016; 1-15.

[5] Dollfus H. Eye involvement in children's rheumatic diseases. Baillere's Clin Rheumatol 1998; 5: 197-202

[6] Soylu M, Ozdemir G, Anli A. Pediatric uveitis in southern Turkey. Ocul Immunol Inflamm 1997; 5:197-202

[7] Hamade $\mathrm{IH}$, Al Shamsi HN, Al Dhibi $\mathrm{H}$, et al. Uveitis survey in children. $\mathrm{Br}$ J Ophthalmol 2009; 93:569-572

Disclosure of Interests: None declared

DOI: 10.1136/annrheumdis-2019-eular.213

\section{AB1209 THE RHEUMA-BUS-TOUR: TWO WEEK OPEN-ACCESS SCREENING FOR EARLY RHEUMATIC DISEASES}

Matthias Dreher ${ }^{1}$, Julia Sauer ${ }^{2}$, Nicolas Scharm ${ }^{3}$, Thomas Plagemann ${ }^{4}$, Gunter Assmann ${ }^{5}$, Kirsten Hoeper ${ }^{6}$, Konstantinos Triantafyllias ${ }^{7}$, Reinhold E. Schmitt ${ }^{8}$, Andreas Schwarting ${ }^{1,2}{ }^{1}{ }^{1}$ University Medical Center of the Johannes Gutenberg University Mainz, Division of Rheumatology and Clinical Immunology, Mainz, Germany, ${ }^{2}$ ACURA Center of Rheumatology Rhineland-Palatinate, Bad Kreuznach, Germany; ${ }^{3}$ University Medical Center of the Johannes Gutenberg University Mainz, Clinic of Maxillofacial, Dental and Oral Diseases, Mainz, Germany, ${ }^{4}$ Leibniz University Hannover, Center for Health Economics Research Hannover, Hannover, Germany; ${ }^{5}$ Saarland University Medical Center, Rheumatology, Homburg, Germany; ${ }^{6}$ Medical School Hannover, Center for Rheumatology Lower Saxony e.V., Hannover, Germany, ${ }^{7}$ ACURA Center of Rheumatology Rhineland-Palatinate, Mainz, Germany; ${ }^{8}$ Medical School Hannover, Department of Clinical Immunology and Rheumatology, Hannover, Germany

Background: Early diagnosis is crucial for patients with rheumatic diseases. Studies show that early stage patients already show reduced mental and physical health [2, 3]. However, early diagnosis is often delayed due to the severe lack of rheumatologists in Germany.

Objectives: The cross-sectional study compares data on physical and mental health of known and suspected early rheumatic patients, collected from participants of the bus tour.

Methods: The Rheuma-Bus-Tour is an annual, two week open-access screening event in three states (Rhineland-Palatine, Saarland, Lower Saxony) that raises awareness for rheumatic diseases and identifies people with potential early cases of RA, SpA and PsA.

All participants, regardless of their diagnosis status, completed a screening questionnaire about early symptoms, sociodemographic as well as physical and mental health parameters: Habitual Physical Activity Questionnaire (HPA) [1], Hannover Functional Ability Questionnaire (FFbh-R), Patient Health Questionnaire (PHQ-9), Well-Being Index (WHO-5).

Additionally, a CRP on-site test and a medical consultation were offered. Results: In total, 853 participants completed the questionnaire, 214 with a known rheumatic diagnosis and 626 without one. Of 533 conducted CRP tests, 107 were positive. After the consultation, 58 patients were referred for an immediate rheumatologist appointment through the Rheuma-VOR network, 16 of which were diagnosed with RA, SpA, or PsA. Tables 1 and 2 present the group differences between the already diagnosed and the not diagnosed groups, split by CRP results.

Abstract AB1209 Table 1. Basic characteristics of the participants

\begin{tabular}{|l|l|l|l|l|l|l}
\hline & \multicolumn{2}{|l|}{$\begin{array}{l}\text { Rheumatic disease } \\
\text { (N=214) }\end{array}$} & \multicolumn{2}{l}{$\begin{array}{l}\text { No Diagnoses+CRP neg } \\
\text { (N=426) }\end{array}$} & \multicolumn{2}{l}{$\begin{array}{l}\text { No Diagnoses+CRP pos } \\
\text { (N=107) }\end{array}$} \\
\hline & Mean & SD & Mean & SD & Mean & SD \\
\hline BMI & 27.6 & 5.5 & 27.2 & 5.0 & 29.0 & 6.6 \\
\hline HPA Work Index & 2.5 & 1.0 & 2.7 & 0.9 & 2.6 & 1.1 \\
\hline HPA Sports Index & 2.4 & 0.9 & 2.4 & 0.8 & 2.2 & 0.9 \\
\hline HPA Leisure Time Index & 3.0 & 0.8 & 3.1 & 0.8 & 3.1 & 0.9 \\
\hline HPA Index & 7.9 & 1.9 & 8.2 & 1.7 & 7.9 & 2.0 \\
\hline FFbH-R & 69.2 & 21.4 & 80.9 & 18.4 & 66.4 & 88.0 \\
\hline PHQ-9 & 17.3 & 6.7 & 16.3 & 5.5 & 15.6 & 6.6 \\
\hline WHO-5 & 16.9 & 7.4 & 15.9 & 6.1 & 15.2 & 7.2 \\
\hline
\end{tabular}

